\title{
NOC/NIC Linkages to NANDA-I for Continence Care of Elderly People with Urinary Incontinence in Nursing Homes: A Systematic Review
}

\author{
Hatice Bebiş ${ }^{1}$ (D), Sue Moorhead ${ }^{2}$ (D), Dercan Gençbaş ${ }^{3}$ (D), Serpil Özdemir ${ }^{4}$ (D) Memnun Seven ${ }^{5}$ (i)
}

\section{DOI: 10.26650/FNJN386150}

ORCID IDs of the authors: H.B. 0000-0001-62179753: S.M. 0000-0002-9517-9909; D.G. 00000002-8053-754X; S.Ö. 0000-0003-0952-3337; M.S. $0000-0002-6981-8877$

${ }^{1}$ Department of Public Health Nursing, Near East University, Nicosia, Cyprus

${ }^{2}$ The University of Iowa College of Nursing, Iowa City, Iowa, USA

${ }^{3}$ Department of Nursing, Atilım University, Faculty of Health Sciences, Ankara, Turkey

${ }^{4}$ Department of Public Health Nursing, Gülhane Faculty of Nursing Health Science University, Ankara, Turkey

${ }^{5}$ Department of Obstetric and Gynecologic Nursing, Koç University, İstanbul, Turkey

\section{Corresponding author:}

Dercan Gençbaș,

Department of Nursing, Attlım University, Faculty of Health Sciences, Ankara, Turkey

E-mail: dgencbas@gmail.com

Date of receipt: 30.01 .2018

Date of acceptance: 17.05.2019

Cite this article as: Bebiș, H., Moorhead, S., Gençbaş, D., Özdemir, S, Seven, M. (2019). NOC/ NIC Linkages to NANDA-I for continence care in nursing homes. FNJN Florence Nightingale Journal of Nursing, 27(3),

https://doi.org/10.26650/FNJN386150

(c) Copyright 2019 by İstanbul University-Cerrahpaşa Florence Nightingale Faculty of Nursing. Available on-line at http://fnjn.istanbulc.edu.tr

\section{ABSTRACT}

Aim: The aim of this study was to review interventional studies conducted by nurses about elderly people with urinary incontinence in nursing homes and to match the results to standardized nursing terminology using the Nursing Interventions Classification and the Nursing Outcomes Classification Linkages to the NANDA-I diagnoses guidelines.

Method: A systematic review of quantitative intervention studies was conducted using the PRISMA statement as a guide. The interventional research in English was scanned using the MEDLINE and CINAHL databases from January 2005 to May 2015. Fourteen studies that had at least one nurse researcher were conducted in nursing homes, excluding surgical and pharmacological interventions. The Nursing Outcome Classification and Nursing Intervention Classification Linkages to NANDA-I diagnoses and the Clinical Conditions Part II-U List were used as a guide to select North American Nursing Diagnosis Association International nursing diagnoses, Nursing Outcome Classification Scales, and Nursing Interventions from the data.

Results: We found the frequency of use of various NANDA-I diagnoses, Nursing Interventions, and Nursing Outcomes based on the Nursing Outcomes Classification and Nursing Interventions Classification Linkages to NANDA-I diagnoses and the Clinical Conditions List for incontinence.

Conclusion: Using the Nursing Outcomes Classification and Nursing Interventions Classification Linkages to NANDA-I diagnoses guide may provide new nursing perspectives on non-standardized research. In future studies, this may allow a comparison of data worldwide, enabling nurses to use the results in evidence-based practices.

Keywords: Intervention, NANDA, NIC, NOC, nursing, older people, systematic review, urinary incontinence 


\section{INTRODUCTION}

Urinary incontinence (UI) is one of the most common and distressing conditions affecting nursing home residents and their nursing staff. It is estimated that UI affects over $50 \%$ of the elderly persons living in nursing homes $(\mathrm{NH})$. The $\mathrm{NH}$ staff report that UI care is difficult, time-consuming, and costly (Flanagan et al., 2015; Park, De Gagne, So, \& Palmer, 2015; Resnick et al., 2006). They have to apply different interventions requiring different skill sets to handle alterations in urinary elimination. The $\mathrm{NH}$ staff not sufficiently specialized in this field should have support to diagnose and manage UI (De Moraes-Lopes, Siqueire-Ortega, Massad, \& Marin, 2009; Vinsnes, 2012; Yu, Hailey, Fleming, \& Traynor, 2014).

Urinary incontinence is defined as an "involuntary loss of urine, which is objectively demonstrable and a social or hygienic problem" (NANDA-I, 2014). Although different variants of UI have been described in prior studies, the five most common types are the stress, urge, mixed, overflow, and functional incontinence (Aslan, Komurcu, Beji, \& Yalcin, 2008; Voith, 2000).

Urinary incontinence has a negative impact on an NH resident's life; moreover, it increases the risks of damaged skin, urinary tract infections, and falls (Rodriguez, Sackley, \& Badger, 2007; Roe, Lisa Flanagan, \& Maden, 2015). Treatment includes surgical, pharmacologic, and behavioral interventions (Bliss, Kay-Savik, Harms, Fan \& Wyman, 2006). Nurses generally use behavioral interventions as the first management options (Palmer, 2008). These interventions include the pelvic floor muscle exercises with or without biofeedback (Aslan et al., 2008), electrical stimulation (Booth et al., 2013), bladder training and systematic voiding programs, individual care plans, exercise programs, and continence care (Schnelle et al., 2003; Palmer, 2008).
In the literature, there is much research available demonstrating the effectiveness of nursing care for elderly people with UI. However, it is unknown whether these research results are connected with nursing practice since current nursing research data are not based on any standardized nursing language. To provide nurses with information about the UI care globally, and to develop new nursing perspectives for elderly people with urinary incontinence living in $\mathrm{NH}$, it is important to use standardized nursing language to understand the data. The NANDA International, the Nursing Interventions Classification (NIC), and the Nursing Outcomes Classification (NOC) are comprehensive, research-based, standardized classifications of nursing diagnoses, nursing interventions, and nursing-sensitive patient outcomes. They provide a set of terms to describe nursing judgments, treatments, and nursing-sensitive patient outcomes in every aspect of nursing care, including elderly patients with UI (De Moraes et al., 2009; Johnson et al., 2012; Noh \& Lee, 2015).

The NOC and NIC Linkages to NANDA-I may provide more useful concepts to help deepen the description, explanation, prediction, and identification of interventions for patient care and the education of nurses (Johnson et al., 2012; Voith, 2000). Moreover, these linkages between nursing diagnoses and interventions can assist the nurses in making decisions about the optimal interventions and the desired outcome for this population (Johnson et al., 2012).

The aim of the study was to systematically review interventional research conducted by nurses on elderly patients with $\mathrm{UI}$ in $\mathrm{NHS}$ to match the standardized nursing language using the NOC and NIC Linkages to NANDA-I and Clinical Conditions Supporting Critical Reasoning and Quality Care. 


\section{METHOD}

\section{Study Design}

We use the PRISMA statement as a guide in this study (Moher, Liberati, Tetzlaff, Altman, \& the PRISMA Group, 2009). The study was designed as a systematic review of quantitative intervention studies and as a narrative synthesis.

\section{Search Strategy}

Electronic versions of interventional studies in English between January 2005 and May 2015 were searched for in MEDLINE and CINAHL via OVID. The search strategy was purposely kept broad to include relevant studies in which a nurse played an important role in the intervention but which excluded surgical and pharmacological interventions. It used keywords including "incontinence," "urinary incontinence," "nurse-led continence," "nursing home staff," "nursing care facility," "nursing home," "nursing classification," "NIC intervention," "NOC outcomes," "NANDA diagnosis," "self-care: toileting," "continence pads," "continence training impact," "elderly with $\mathrm{UI}$," and "quality of life."

\section{Inclusion and Exclusion Criteria}

The systematic review consisted of studies including randomized controlled trials (RCT), quasi-RCT, quasi-experimental studies, and pretest/posttest studies or one-group intervention. These studies had to meet the following requirements: to have been published in English between 2005 and 2015, to have had either at least one nurse researcher on the research team or interventions that were carried out by a nurse, and to have been conducted in an $\mathrm{NH}$ setting (residential homes, long-term care). The research study samples had to comprise elderly patients aged 65 years and above living in $\mathrm{NH}$ care settings. All of the studies focused on the management of incontinence, and the pro- motion and maintenance of continence. Any studies conducted in settings other than $\mathrm{NH}$, in different age groups other than $\geq 65$ years, or on inpatient groups without any type of UI were excluded from the systematic review.

\section{Search Outcome}

As a result of the initial search, we identified 293 potential papers for inclusion, and a search by hand found five additional studies $(n=298)$. Further to this process, duplicated studies $(n=45)$ were deleted, meaning that 253 papers were left for examination. After reading the titles of all the papers, a further 106 were excluded because they did not meet the review criteria, leaving a total of 147. Following this, we read the abstracts of the studies and excluded studies that did not comply with the criteria. We located 56 studies, including seven systematic reviews. Forty-nine studies were original articles. The remaining papers were read in full, but only 14 studies were interventional studies that involved a nurse playing an important role or who was at the least a member of the research team (Figure 1).

\section{Quality Appraisal}

All studies were independently examined for inclusion/exclusion criteria by three reviewers using a standard form, and a consensus was reached. The "Quality Assessment of Controlled Intervention Studies" (14 item) and the "Quality Assessment Tool for Before-After (Pre-Post) Studies with no Control Group" (12 item) provided by the National Institutes of Health were used for quality assessment (NHBLI, 2014), which allowed a consistent approach for assessment. Three of the authors (HB, DA, and SO) independently evaluated each paper and then reached a consensus. The majority of studies were at a good level. No studies were excluded on the basis of the quality assessment. 


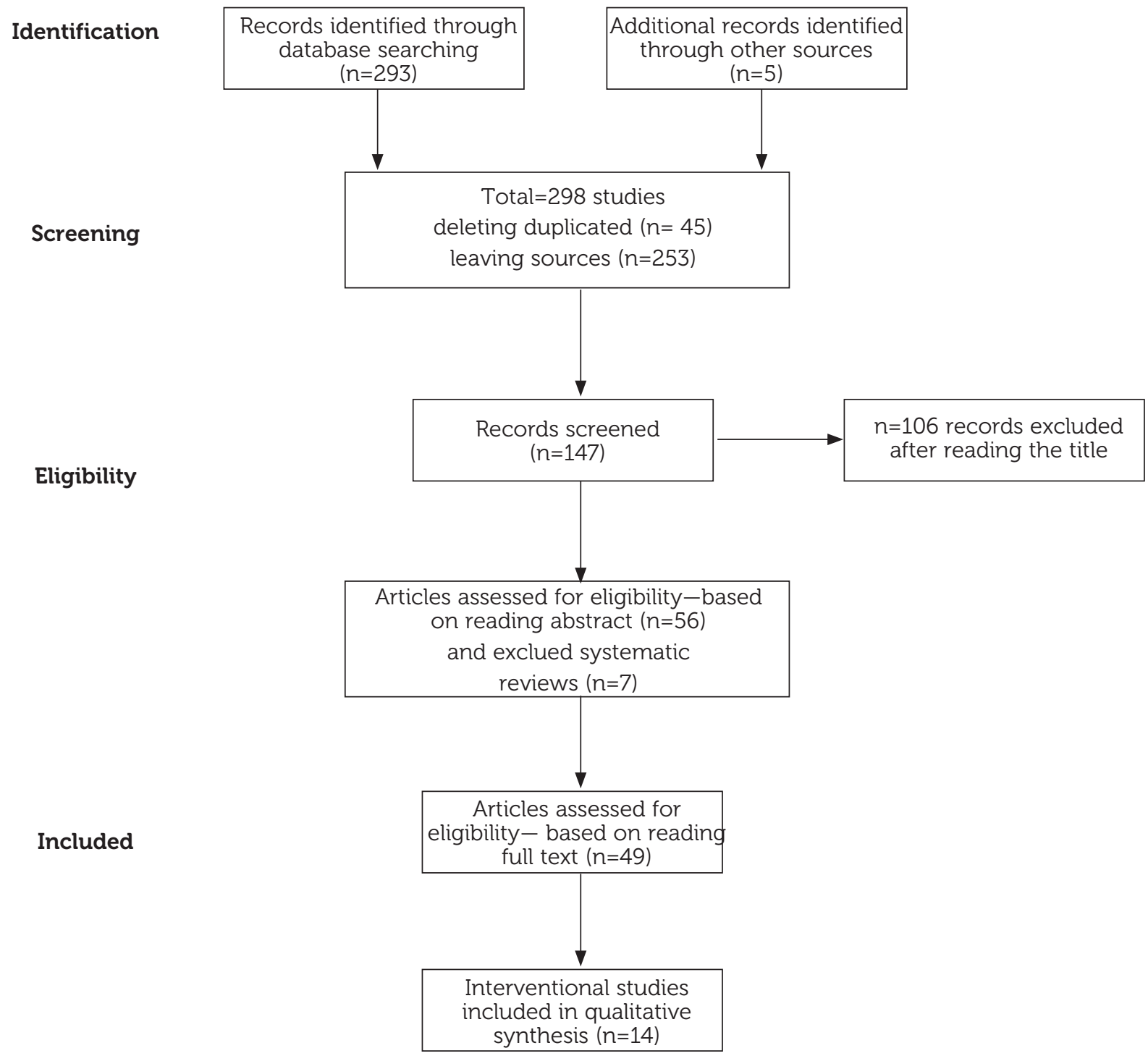

Figure 1. Study design

\section{Data Extraction}

A primary researcher developed a form to be used independently by the three researchers to extract standardized information from all studies. They reached an agreement on the accuracy of the data.

\section{Data Synthesis}

Although the main concern was with the elderly with $\mathrm{UI}$ in $\mathrm{NHs}$, the studies included varied in terms of aims, methods, outcome measures, results, limitations, and implications for practice.

\section{NOC and NIC Linkages to NANDA-I}

In this review, we used the NOC and NIC Linkages to NANDA-I and the Clinical Conditions Supporting Critical Reasoning and Quality Care as guides (Johnson et al., 2012), and the studies were matched independently by three reviewers. The reviewers resolved any potential disagreements through discussion. A fourth reviewer who was an expert on NANDA/NIC and NOC Linkages then reviewed the results and decided if the NANDA-I diagnoses, NIC interventions, and NOC outcomes for UI care used in the study fitted. 
This guide suggested eight NANDA-I diagnoses, five NOC outcomes, and 11 major and 35 suggested NIC interventions (Johnson et al., 2012). These NIC interventions were grouped together by the researchers under the headings "Training/Teaching," "Management/Monitoring," "Care," and "Documentation." In this step, each study was evaluated to find possible NANDA diagnoses, NOC outcomes and NIC interventions.

If the UI type had been determined by the research before the study, or the intervention was applied for a specific type of incontinence, this was selected as one possible specific NANDA diagnosis ("Overflow," "Reflex," etc.). If interventions were aimed at caring for symptoms of incontinence or continence management, the "Urinary Elimination, Readiness for Enhanced" was chosen as a possible NANDA diagnosis.

After the NANDA diagnosis was determined, we investigated the studies to match possible NIC/NOC Linkages to each of determined NANDA diagnoses. As we investigated possible NIC/NOC Linkages, we noted words commonly used in the studies. These were "observe," "physical mobility," "communicate," "documentation," "training," "teach," "impaired skin integrity," "self-care," "self-care toileting," "incontinence care," "exercise," "bladder training," "toileting schedule," "individual care plan," "consultant," "medication management," "fluid intake monitoring-management," and "perineal care." We used those words that were critical cues in selecting particular NIC interventions and NOC outcomes (Tables 1, Table 2).

\section{RESULTS}

This study reports on 14 nursing intervention studies from different countries. Thirty-six NANDA-I diagnoses were determined. For each study, at least two and at most four NAN-
DA-I diagnoses were selected. A total of 37.1\% of the diagnoses were "Urinary Elimination Impaired" (13 studies); 34.2\% were "Urinary Elimination Readiness for Enhanced" (11 studies); 8.5\% were "Urinary Incontinence: Urge" (three studies); $5.7 \%$ were "Urinary Retention" (two studies); $5.7 \%$ were "Urinary Incontinence: Functional" (two studies); and 2.8\% were "Urinary Incontinence: Overflow" (one study) (Tables 1, Table 2).

There were 167 nursing interventions determined to have occurred in these studies. The studies examined eight training/teaching interventions, seven management/monitoring interventions, 10 care interventions, and two documentation interventions.

Forty-four possible NOC outcomes were determined in these studies. Each study had between two and five NOC outcomes. The most selected possible NOC outcome was "Urinary Elimination" (31.8\%) (Tables 1, Table 2).

We separated the studies into two categories according to their primary aim. Some of these studies aimed to assess the effects of multi-intervention programs on incontinence-associated dermatitis (IAD) and skin integrity as a primary aim (Table 1). Other studies involved urinary decrease, continence promotion, or UI complication prevention, with an enhanced quality of life as the primary aim (Table 2).

\section{Skin Integrity and Skin Care Studies}

The primary aim of four studies was to promote skin integrity through preventing IAD and pressure ulcers and to provide treatment and healing. For these four studies, we matched possible NANDA diagnoses of "Urinary Elimination Impaired" and "Urinary Elimination Readiness for Enhanced." A diagnosis of "Urinary Incontinence: Urge" was added to one study because the researcher had determined this specific type of incontinence prior to the study (Palese et al., 2011). The interventions in these studies were 
Table 1. NANDA diagnoses/NOC outcomes/NIC intervention for primary aim was skin integrity and skin care studies

\begin{tabular}{|c|c|c|c|c|c|}
\hline Author & Country & Method/Intervention & Participants & Results & NANDA/NOC/NIC \\
\hline $\begin{array}{l}\text { 1. Al-Samarrai } \\
\text { N.R., et al. } \\
(2007)\end{array}$ & $\begin{array}{l}\text { United } \\
\text { States of } \\
\text { America } \\
\text { (USA) }\end{array}$ & $\begin{array}{l}\text { Method: } \\
\text { The quasi-experimental/ } \\
\text { controlled trial study. } \\
\text { Study Interventions: } \\
\text { 1. OSIS: Intervention group } \\
\text { 2. BW: control group } \\
\text { Study outcomes: } \\
\text { 1. Resident location, tho- } \\
\text { roughness and duration } \\
\text { of incontinence care, and } \\
\text { materials used } \\
\text { 2. CNAs' opinions of their } \\
\text { preferred incontinence care } \\
\text { materials and their experien- } \\
\text { ce using OSIS were obtained } \\
\text { by self-administered survey. }\end{array}$ & $\begin{array}{l}\text { Study area: } \\
\text { Two NHs Participants: } \\
\text { Data obtain } 24 \text { inconti- } \\
\text { nent NH residents and } \\
61 \text { CNAs Intervention } \\
\text { applied: } 61 \text { CNAs } \\
\end{array}$ & $\begin{array}{l}\text { 1. The OSIS is effective for } \\
\text { management of urinary, } \\
\text { - fecal, and combined (uri- } \\
\text { nary plus fecal) inconti- } \\
\text { nence. } \\
\text { 2. CNAs used two wipes } \\
\text { from OSIS to sanitize the } \\
\text { perineal area } \\
\text { 3. CNAs were more likely } \\
\text { to report that they felt that } \\
\text { OSIS facilitated skin clean- } \\
\text { sing compared to the BW. }\end{array}$ & $\begin{array}{l}\text { NANDA-I Diagnoses: } \\
\text { 1.Urinary Elimination Impaired } \\
\text { 2.Urinary Elimination Readiness } \\
\text { for Enhanced } \\
\text { NOC Outcomes: } \\
\text { 1.Urinary Elimination } \\
\text { 2.Tisue İntegrity: Skın and } \\
\text { Mucous Membranes } \\
\text { NIC Intervention: } \\
\text { Management/Monitoring } \\
\text { 1.Urinary Elimination } \\
\text { Management 2.Infection } \\
\text { Protection } \\
\text { Care } \\
\text { 1.Urinary Incontinence Care } \\
\text { 2.Perineal Care }\end{array}$ \\
\hline
\end{tabular}

\section{Thompson USA \\ P., et al.}

(2005)

3. Palese A., Italy et al. (2011)

\section{Method: period. \\ Study Interventions: \\ 1. During the 3-month peri- od, skin assessment data and information on PrU development, treatment, healing time, and inconti- nence were documented. 2. An educational session was conducted for all nur- sing staff. \\ 3. Nursing staff were instru- cted to cleanse the skin with the body wash after each incontinent episode and to apply the skin protectant to the perineal/perianal area after each cleansing. Study Outcomes: \\ 1. Braden Scale for Predicting \\ Pressure Sore Risk used}

\section{Method: \\ Study area:}

Single-group, pre-/post inter-In an 82-bed NH vention study.

Intervention:

1. Initial assessment of incontinence care (phase 0 , 14 days)

2. Use of new absorbent products and a structured skin care regimen in (phase 1, 14 days)

3. Follow-up 21 days

Study Outcomes:

1. Barthel Index

2. Norton Scale

3. medication, UI type,- pad changes per day and use of absorbent products, use of products for perineal skin care

\section{A total of $63.3 \%$ of the NANDA-I Diagnoses:} residents in the study had 1.Urinary Elimination Impaired urinary incontinence. $\quad 2$. Urinary Elimination Readiness Participants: 2. The prevalence of PrUs for Enhanced A total of 136 residents was $11.3 \%$ preintervention NOC Outcomes: (70\% females and $30 \%$ and $4.8 \%$ postintervention; 1.Urinary Elimination males) the incidence was 32.7\% 2.Tissue İntegrity: Skin and Intervention applied: preintervention and 8.9\% Mucous Membranes A total of $84 \%$ of licen- postintervention. NIC Intervention: sed staff and $72 \%$ of $\quad 3$. Healing times signifi- Management/Monitoring unlicensed staff in cantly decreased for Stage 1.Urinary Elimination both agencies. I and Stage II PrUs, from Management 2.Infection a mean of nearly 23 days Protection preintervention to 16 days Care postintervention, indication1.Umary incontinence care that chronic wounds in 2.Perineal care older adults heal with early treatment.

\section{Participants:}

63 residents $(46$ women and 17 men)

Intervention apply: ses' aides (CNAs) pro- Phase $3=21$

vided round-the-clock 4. Clinical impact:

care to residents. - At baseline, IAD was

Nursing home staff $\quad 31.7 \%$. After (Phase 2), IA

had not received previ-was $3.1 \%$.

ses on UI care from risk of IAD was 0.24, Phase Management the facility

$\begin{array}{ll}\text { I the relative risk of IAD } & \text { 2. Medication Management }\end{array}$ was further diminished to 3. Infection Protection 0.15 . The final phase of the Care study reduced the relative 1 . Urinary incontinence care risk of IAD to 0.03 (95\% CI). 2. Perineal Care Documentation 1. Documentation 
Table 1. NANDA diagnoses/NOC outcomes/NIC intervention for primary aim was skin integrity and skin care studies (continued)

\begin{tabular}{|c|c|c|c|c|c|}
\hline Author & Country & Method/Intervention & Participants & Results & NANDA/NOC/NIC \\
\hline $\begin{array}{l}\text { 4. Beeckman D., } \\
\text { et al. (2011) }\end{array}$ & & $\begin{array}{l}\text { Method: } \\
\text { Randomized, control- } \\
\text { led clinical trial Study } \\
\text { Interventions: } \\
\text { Experimental group was } \\
\text { treated with a 3-in-1 perineal } \\
\text { care washcloth impregnated } \\
\text { with a 3\% dimethicone skin } \\
\text { protectant. } \\
\text { - for daily routine perineal } \\
\text { skin hygiene - after each dia-c } \\
\text { per/underpad change } \\
\text { 2. Control group received } \\
\text { the standard of care (water } \\
\text { and a pH-neutral soap). } \\
\text { 3. No additional skin protec- } \\
\text { tant was applied } \\
\text { 4. If clinical signs of cuta- } \\
\text { neous bacterial or fungal } \\
\text { infection occurred, the } \\
\text { general practitioner of the } \\
\text { resident was consulted and } \\
\text { prescribed } \\
\text { Study Outcomes: } \\
\text { 1. IAD Skin Condition } \\
\text { Assessment Tool. 2. Skin } \\
\text { observation (use of a trans- } \\
\text { parent disc/finger method to } \\
\text { differ blanchable from nonb- } \\
\text { lanchable erythema) and }\end{array}$ & $\begin{array}{l}\text { Study area: } \\
\text { Eleven NHs (six expe- } \\
\text { rimental, five cont- } \\
\text { rol) N=464 nursing } \\
\text { home residents were } \\
\text { lobserved in this trial } \\
\text { Participants: } \\
\text { A total of } 141 \text { (32.9\%) } \\
\text { were described for } \\
\text { study (experimental 73, } \\
\text {-control 68) } \\
\text { Intervention applied: } \\
\text { By six researchers (they } \\
\text { trained all nurses and } \\
\text { health care assistants } \\
\text { in both groups using } \\
\text { interactive, small-group } \\
\text { educational sessions } \\
\text { regarding) For the staff, } \\
\text { posters and pocket } \\
\text { cards were developed } \\
\text { about the application } \\
\text { of the perineal care } \\
\text { washcloth and the skin } \\
\text { care. }\end{array}$ & $\begin{array}{l}\text { 1. The mean age of the } \\
\text { residents was } 86.3 \text { years. } \\
\text { 2. In both groups, approxi- } \\
\text { mately } 60 \% \text { incontinent for } \\
\text { urine, } 30 \% \text { for feces, } 10 \% \\
\text { for urine/feces. } \\
\text { 3. Baseline IAD prevalence } \\
\text { experimental } 22.3 \% \text { cont- } \\
\text { rol; } 22.8 \% \text {, (p>0.05) group } \\
\text { (Day 1: } 22.3 \% \text {; Day } 120 \text { : } \\
\text { 8.1\%, p=0.001). } \\
\text { 4. In contrast, the prevalen- } \\
\text { ce of IAD significantly dec- } \\
\text { reased in the experimental } \\
\text { IAD prevalence increased } \\
\text { in the control group (Day } \\
1: 22.8 \% \text {; Day } 120 \text { : } 27.1 \% \text {, } \\
\text { p=0. 003). - Characteristics } \\
\text { and Formula of the } \\
\text { Experimental Product may } \\
\text { have reduced rubbing over } \\
\text { the perineal skin to remo- } \\
\text { ve urine/feces, which may } \\
\text { have caused a reduction in } \\
\text { friction damage. } \\
\text { 5. The baseline IAD seve- } \\
\text { rity was } 6.9 / 10 \text { in the expe- } \\
\text { rimental group and } 7.3 / 10 \\
\text { in the control group. } \\
\text { 7. A significant intervention } \\
\text { effect on IAD prevalence } \\
\text { was found in the experi- } \\
\text { mental (8.1\%) vs. the cont- } \\
\text { rol group ( } 27.1 \% \text { ) (p=0.003) }\end{array}$ & $\begin{array}{l}\text { NANDA-I Diagnoses: } \\
\text { 1. Urinary Elimination Impaired } \\
\text { 2. Urinary Elimination Readiness } \\
\text { rfor Enhanced } \\
\text { NOC Outcomes: } \\
\text { 1. Urinary Elimination } \\
\text { 2. Tissue Integrity: Skin and } \\
\text { Mucous Membranes } \\
\text { NIC Intervention: } \\
\text { Management/Monitoring } \\
\text { 1. Urinary Elimination } \\
\text { 2. Management } \\
\text { 3. Infection Protection } \\
\text { 4. Pain Management } \\
\text { Care: } \\
\text { 1. Urinary incontinence care } \\
\text { 2. Perineal Care } \\
\text { Documentation: } \\
\text { 1. Documentation } \\
\end{array}$ \\
\hline
\end{tabular}

carried out by nurses/certificated nurse assistants (CNAs) (approximately $n=100$ ), who underwent training programs before the studies about skin observation, the differentiation between IAD and pressure ulcers, symptoms of incontinence symptoms, and treatment/care. Training programs were conducted using different approaches (interactive education activity, smallgroup discussion, etc.) in each study (Table 1).

In one study, the researcher observed the incontinence care practices of CNAs in an $\mathrm{NH}$, including location and thoroughness of care, and amount and type of materials used (Al-Samarrai, Uman, Al-Samarrai T., \& Alessi, 2007). In $23 \%$ of the observations, the CNAs interrupted IU care to leave the room to get more supplies. In the study by Thomson et al. (2005), the di- rectors of nursing monitored and reinforced the $\mathrm{NH}$ staff's compliance to protocols on an ongoing basis. Healing times significantly decreased in this period. Palese et al. (2011) determined the prevalence of UI as $79.7 \%$. This study measured a baseline IAD of $31.7 \%$; after treatment, IAD was at $3.1 \%$. We were able to identify three essential NIC interventions under the "Management/Monitoring" heading ("Urinary Elimination Management," "Infection Protection," "Medication Management," "Pain Management"), the "Care" heading ("Urinary Incontinence Care," "Perineal Care"), and the "Documentation" heading ("Documentation") (Table 1).

In all of the studies, residents were observed over different periods, skin assessments were 
Table 2. NANDA/NOC/NIC for primary aim was incontinence management studies

\begin{tabular}{|c|c|c|c|c|c|}
\hline Author & Country & Method/Intenvention & Participants & Results & NANDA/NOC/NIC \\
\hline $\begin{array}{l}\text { 1. Booth J., } \\
\text { et al. (2013) }\end{array}$ & $\begin{array}{l}\text { United } \\
\text { Kingdom } \\
\text { (UK) }\end{array}$ & $\begin{array}{l}\text { Method: } \\
\text { Pilot randomized } \\
\text { single-blind, placebo } \\
\text {-controlled trial. } \\
\text { Study Interventions: } \\
\text { 1. A standardized history } \\
\text { and physical examination, } \\
\text { sensory testing, urinalysis, } \\
\text { and postvoid residual } \\
\text { urine volume measurement } \\
\text { 2. A 12-session TPTNS } \\
\text { treatment programmed } \\
\text { (each treatment session } \\
\text { 30 minutes, twice a week, } \\
\text { over a continuous } 6 \\
\text { week period) } \\
\text { Study Outcomes: } \\
\text { 1. The resident and staff } \\
\text { were blinded to the } \\
\text { group allocation } \\
\text { 2. Postvoid residual urine } \\
\text { volumes using portable } \\
\text { bladder scanning } \\
\text { 3.Acceptability of the }\end{array}$ & $\begin{array}{l}\text { Study area: } \\
\text { Seven residential care } \\
\text { homes and three } \\
\text { sheltered for } 8 \text { months } \\
\text { ( } N=206) \text {. } \\
\text { Participants: } \\
\text { - } 30 \text { care home residents } \\
\text { ( } n=15 \text { TPTN/ } n=15 \text { placebo) } \\
\text { - aged } 65 \text { and older with } \\
\text { urinary or bowel symptoms } \\
\text { and/or incontinence } \\
\text { Intervention applied: } \\
\text { Two staff (nurse) }\end{array}$ & $\begin{array}{l}\text { 1. The mean age was } \\
84.2 \text { years }(80 \%, n=24) \\
\text { 2. UI was the predominant } \\
\text { dysfunction in } 50 \% \text { ( } n=15) \\
\text { 3. Retention of participants } \\
\text { throughout the } 6 \text {-week } \\
\text { intervention period } \\
\text { was good. } \\
\text { 4. Acceptability of the } \\
\text { TPTNS was high } \\
\text { throughout with no reports } \\
\text { of any adverse effects, } \\
\text { either by the participant } \\
\text { or staff. } \\
\text { 5. Urinary symptoms: } \\
\text { Improved in } 13 \text { ( } 87 \%) \\
\text { patients from the TPTNS } \\
\text { group and worsened } \\
\text { in two (13\%) }\end{array}$ & $\begin{array}{l}\text { NANDA-I Diagnoses: } \\
\text { 1. Urinary Elimination } \\
\text { Impaired } \\
\text { 2. Urinary Elimination } \\
\text { Readiness for Enhanced } \\
\text { 3. Urinary Incontinence: Urge } \\
\text { 4. Urinary retention } \\
\text { NOC Outcomes: } \\
\text { 1. Urinary Elimination } \\
\text { 2. Urinary Continence } \\
\text { NIC Intervention: } \\
\text { Training/Teaching } \\
\text { 1. Urinary Bladder Training } \\
\text { 2. Urinary Habit Training } \\
\text { 3. Teaching: Procedure/ } \\
\text { Treatment } \\
\text { Management/Monitoring } \\
\text { 1. Urinary Elimination } \\
\text { Management } \\
\text { 2. Infection Protection } \\
\text { 3. Pain Management } \\
\text { Care } \\
\text { 1. Urinary retention care } \\
\text { 2. Urinary incontinence care }\end{array}$ \\
\hline
\end{tabular}

\section{Aslan E., Turkey et al. (2008)}

3. Tanaka Y., Japan et al. (2009)

TPTNS and adverse effects were assessed at each session by asking the resident

\section{Method:}

An experimental prospective research study Study Interventions:

1. Bladder training

2. Kegel exercises were given to the retreatment group for 6-8 weeks.

\section{Study Outcomes:}

1.First evaluation:

- Quality of Life Scale,

Mini-mental Test,

Ranking Scale

- Daily urinary forms used

- Pad tests

- Pelvic floor muscle strength

2. The second evaluation

was performed 8 weeks after treatment.

3. The last evaluation was carried out 6 months after treatment (major measurement was urinary incontinence with urgency, frequency, and nocturia complaints, and in the pad test results and pelvic flor strength evaluation) $1 \mathrm{NH}$ care (female $\mathrm{n}=191$ )

\section{Method:}

An intervention study

\section{Study area:} (pre-/post-) no control group. 1290 residents

\section{Study area: \\ Participants:}

Woman residents $n=50$

(25 from treatment group, 25 from the control group) Intervention applied:

By researcher nurse $(n=1)$

In $17 \mathrm{NH}$, there were
1. The average age of residents was 78.8 years. 2. $52 \%$ in the treatment group had the mixed IU. $60 \%$ the control group had the urge IU.

3. the pelvic floor muscle $-1-2 / 5$ weakness in $52 \%$ in the treatment group and $48 \%$ in the control group 4. After the study was found in urgency $(52 \%)$, frequency (64\%), and nocturia (32\%) complaints in treatment group decreased 5. King Health Questionnaire 3. Teaching: Procedure/ results showed that urinary Treatment

incontinence did not affect 4. Teaching: Individual the women to a serious degree.

6. The pad tests of the treatment group, showed that the percentage of severe wetting (11-59 g) was $24 \%$, while the percentage of wetting for the control group was $16 \%$ ( $p>0.005)$.

1. The mean age of residents was 85.2 years.

2. Staff members were
NANDA-I Diagnoses:

1. Uninary Elimination Impaired

2. Urinary Elimination Readiness for Enhanced

3. Urinary Incontinence: Urge 4. Uninary Incontinence: Stress NOC Outcomes:

1. Urinary Elimination

2. Self-Care Toileting

3. Urinary Continence

NIC Intervention:

Training/Teaching

1. Urinary Bladder Training

2. Urinary Habit Training 5. Pelvic Muscle Exercise Management/Monitoring

1.Urinary Elimination

Management

Care

1. Urinary retention care

2. Urinary incontinence care

3. Perineal care

4. Self-care/assistance toileting

5. Prompted voiding

\section{NANDA-I Diagnoses:}

1. Urinary Elimination Readiness for Enhanced 
Table 2. NANDA/NOC/NIC for primary aim was incontinence management studies (continued)

\begin{tabular}{ll}
\hline Author Country & Method/Intervention \\
\hline Study Interventions: \\
1. Seventeen staff members \\
including training chiefs of \\
staff nurses, who in tum \\
trained other staff and \\
encouraging residents. \\
2. An individualized and \\
comprehensive care \\
strategy include \\
- To encourage complete \\
meal intake \\
- To increase fluid intake up \\
to 1500 ml/day \\
- To encourage urination \\
in a toilet \\
- To encourage spending \\
time out of bed for longer \\
than 6 hours \\
- To reduce time spent in \\
wet diapers \\
- To choose diapers with \\
smaller pads to improve skin \\
condition and lower costs \\
Study Outcomes: \\
1. Three-day mean water \\
intakes \\
2. Hours spent in wet diapers \\
3. Comparing the size of the \\
diaper (24 combination \\
patterns)
\end{tabular}

Results NANDA/NOC/NIC

Participants: $\quad$ seldom trained to accurately 2. Urinary Incontinence:

A total of 153 elderly subjects measure the volume of were selected, but complete food intake (the volume data were obtained from was $800 \mathrm{ml}$ before, and $n=122$ residents. Intervention applied: the mean volume was Functional NOC Outcomes:

1. Urinary Elimination 2. Self-Care Toileting

3. Urinary Continence Seventeen staff nurses and increased after intervention 4. Tissue Integrity: Skin who in tum training staff, $\quad(p<0.001)$.

but each elderly for 1.5 staff. 3. In one-fourth of residents, and Mucous Membranes there was an improvement Training/Teaching such as changing from diapers to pants or from larger to smaller pads. 3. The mean time that residents spent before changing from wet diapers to clean ones decreased $(p<0.001)$. 4. The method of urination during daytime did not significantly change before and after the intervention ( $p>0.05$ ); but that method showed an improvement during nighttime $(p=0.007)$.

1. Urinary bladder training
2. Urinary habit training

3. Teaching: Procedure/ treatment

4. Teaching: Individual

5. Pelvic Muscle Exercise

6. Exercise Therapy:

Ambulation

7. Communication: Enhancement

Management/Monitoring

1. Urinary Elimination

Management

2. Fluid Management/

Monitoring

3. Infection Protection

Care

1. Urinary incontinence care

2. Perineal Care

3. Self-Care: Assistance

Toileting

4. Prompted Voiding

Documentation

1. Surveillance: Safe

2. Documentation

4. Schnelle USA J.F., et al. (2010)

\author{
Method: \\ Randomized controlled trial \\ Intervention: \\ 1. Subjects were tended \\ every 2 hours for 8 hours \\ per day over 3 months. \\ This nurses provided: \\ - toileting assistance, \\ - exercise, and \\ - choice of food and fluid \\ (snacks) \\ 2. Trained research staff \\ checked each participant \\ every 2 hours (who were \\ changed in the morning to \\ ensure dry undergarments), \\ and during each subsequent \\ check, research staff \\ thoroughly checked the \\ participant's clothes for \\ evidence of incontinence \\ (e.g., wetness or fecal matter). \\ 3. Research staff provided \\ incontinence care \\ (changing of soiled garments).
}

Study area: $\mathrm{N}=495$
Six nursing homes (NHs).

Participants:

A total of $112 \mathrm{NH}$ residents from the intervention $(n=56)$ or control $(n=56)$ groups completed the 12-week intervention. Intervention applied: Nurse research staff $(n=2)$

1. Two observers recorded the incontinence status (a total of 2,348 incontinence statuses)

2. Intervention subjects scored significantly higher than control subjects at baseline on the MMSE total score $(t=2.09, p=0.04)$ and the number of sit-to-stands ( $\mathrm{t}=2.91, \mathrm{p}=0.01$ ).

3. The intervention group showed a significant increase from the baseline on the following measures (per person, per day) compared to the control group:

- Fluid intake $(p=0.001)$

- Calories from snacks between meals ( $p=0.001)$

- Number of activities $(p=0.001)$

- Number of minutes in
NANDA-I Diagnoses: 1. Urinary Elimination: Impaired 2. Urinary Elimination, Readiness for Enhanced 5. Tissue integrity: Skin and Mucous Membranes NOC Outcomes:

1. Urinary Elimination

2. Self-Care Toileting

3. Urinary Continence 4. Medication Response NIC Intervention:

1. Urinary Bladder Training

2. Urinary Habit Training

3. Teaching: Prescription Medication

4. Teaching: Procedure/ Treatment

5. Teaching: Individual

6. Pelvic Muscle Exercise

7. Exercise Therapy/

Ambulation

8. Communication

Enhancement 
Table 2. NANDA/NOC/NIC for primary aim was incontinence management studies (continued)

\begin{tabular}{ll}
\hline Author Country & Method/Intervention \\
\hline Study Outcomes: \\
1. Frequency of UI and FI \\
2. Rate of appropriate toileting \\
3. Anorectal assessments \\
4. Mini-mental State
\end{tabular}

5. Lin S-Y., Taiwan et al. (2013)

\section{Klay M., USA} et al. (2005)

\section{Method:}

A quasi-experimental study with a pretest and posttest. Intervention:

1. The participants were assigned to the same fluid regimen chosen by their nursing administrator in 6 weeks.

2. In the maintained fluid group, residents were able to consume beverages based on their preference without any limitations on the amount and types. 3. Residents in the increasing fluid group were advised to increase their daily fluids over $1500 \mathrm{ml}$, and the type of beverage (e.g., water, juice, and tea) was not restricted. 4. Urine specimens were collected by nurses at baseline (T1) and at the end of fluid regimen (T2) for urine culture and urine specific gravity.

Study Outcomes:

1. Barthel Index

2. The Short Portable Mental

Status Questionnaire

3. Mini-nutritional Assessment

4. The intake and output checklist:

- Voiding frequency

- Voiding volume

- Beverage types,

\section{Study area:}

Six NH with 30-120 beds $(\mathrm{N}=240)$

\section{Participants:}

Resident ( $\mathrm{n}=74$ )

Intervention applied:

294 staff (159 nurses,

36 head nurses, 99 CNAs)
Results

activities $(p=0.001)$

4. The intervention had a

significan $t$ effect on

frequency

Examination (MMSE)

assessments of UI, FI, and other variables (treatment coefficient):

- UI ( $p=0.07)$; appropriate toileting percentage coefficient $(p=0.000)$. - Higher fluid intake, MMSE score, laxative use, and baseline frequency of UI were associated with higher UI rates during intervention
1. No difference between the two groups (age, daily activities, cognitive function, nutrition status, number of medications, the degree of bladder control, incontinence, and UTI), and their mean age was 75.2 years.

2. At baseline, the prevalence of asymptomatic bacteriuria was $29.7 \%$, and $17.6 \%$ at the 6-week follow-up, but the hypothesis was not supported 3. Prevalence of ASB in residents was $29.7 \%$ at $\mathrm{T} 1$ and $17.6 \%$ at $\mathrm{T} 2$, 4. The proportion of bacteriuria within subjects reached a significant difference between T2 and T1. Particularly, 22.7\% of bacteriuric residents in the increasing fluid group converted to negative urine cultures.

5. Gram-negative species were more than Gram -positive species at T1 and T2. Enterobacteriacea was the most common species.

\section{NANDA/NOC/NIC}

Management/Monitoring

1. Urinary Elimination

Management

2. Environmental Management

3. Medication Management/ Administration

4. Medication Reconciliation

5. Fluid Management/ Monitoring

6. Weight Management Infection Protection

Care

1. Uninary incontinence care

2. Self-Care Assistance $r$ Toileting

3. Prompted Voiding Documentation

1. Surveillance: Safety

2. Documentation

NANDA-I Diagnoses:

1. Uninary Elimination Impaired 2. Uninary Elimination Readiness

for Enhanced

NOC Outcomes:

1. Urinary Elimination

2. Self-Care Toileting

3. Urinary Continence

4. Tissue Integrity: Skin

and Mucous Membranes

NIC Intervention:

Training/Teaching

1. Urinary Bladder Training

2. Urinary Habit Training

3. Communication

Enhancement

Management/Monitoring

1. Urinary Elimination

Management

2. Fluid Management /

Monitoring

3. Infection Protection

4. Specimen Management

Care

1. Urinary incontinence care

2. Perineal Care

3. Urinary Tube Care

4. Uninary Catheterization

5. U.C. Intermittent

6. Self-Care Assistance

Toileting

7. Prompted Voiding

Documentation

1. documentation
Method: Study area:

One-group intervention study One-center (long-term Intervention:

An advanced practice care facilities)

( $\mathrm{N}=120$ residents)
1. All 42 patients were female, the average age was 80 , and $55 \%$ held a diagnosis of dementia.

\section{NANDA-I Diagnoses:}

1. Urinary Elimination Impaired 2. Urinary Incontinence: 
Table 2. NANDA/NOC/NIC for primary aim was incontinence management studies (continued)

\begin{tabular}{|c|c|c|c|}
\hline Author & Country & Method/Intervention & Participants \\
\hline & & $\begin{array}{l}\text { continence specialist (RN) } \\
\text { 1. Incontinent episodes for } \\
\text { each participant were } \\
\text { recorded for a week. } \\
\text { 2. An individualized plan of } \\
\text { care for each patient was } \\
\text { developed. } \\
\text { 3. The plan of care } \\
\text { (medications, diagnoses, and } \\
\text { activities of daily living) was } \\
\text { implemented for at least 1 year. } \\
\text { Study Outcomes: } \\
\text { Patient outcomes were } \\
\text { obtained from the residents' } \\
\text { medical records and } \\
\text { documentation: } \\
\text { 1. The total number of } \\
\text { incontinent episodes } \\
\text { 2. The ITU rate } \\
\text { 3. The pressure sore rate, } \\
\text { and falls rate } \\
\text { 4. A cystometrogram (CMG) } \\
\text { was performed, which } \\
\text { confirmed an overactive } \\
\text { bladder. }\end{array}$ & $\begin{array}{l}\text { Participants: } \\
\text { Forty-two female residents } \\
\text { who were incontinent } \\
\text { or had urgency related } \\
\text { to overactive bladder } \\
\text { Intervention applied: } \\
\text { An advanced practice } \\
\text { registered nurse } \\
\text { continence specialist } \\
\end{array}$ \\
\hline
\end{tabular}

7. Yu P., Australia Method:

et al. (2014)
A quasi-experimental field design with pre-

/postintervention

Study Interventions:

1. The intervention was a new UC care plan and its implementation in care practice.

five to eight older people were assessed each week.

It took 5 weeks to complete the T1 step.

2. The result of the telemonitoring UC assessment was used by a continence consultant to develop an individualized

\section{Study area:}

A 120-bed NH during a

12-week trial

Participants:

Evaluate a total of 32

residents.

Data collected 31 from residents

Intervention applied:

s, A total of 121 care staff wh used the UC telemonitoring system.

UC care was mainly provided by personal care workers (PCWs), who have a minimum qualification, such as a Certificate III in aged care awarded by the Technical and Further

\section{Results}

2. The number of uninary

incontinence episodes rose which might be due to an advanced age.

3. Patients treated with biofeedback were also better able to notice the signal to void.

- The UTI rates dropped rom $5 \%$ to $1 \%$,

- Pressure sore rates dropped from $80 \%$ to $45 \%$

- The falls decreased by more than $50 \%$.

- Overall, the 42 residents were 100 more time s drier per week.

NANDA/NOC/NIC

Overflow

3. Urinary Incontinence: Urge NOC Outcomes:

1. Urinary Elimination

2. Self-Care Toileting

3. Urinary Continence

4. Medication Response

5. Tissue Integrity: Skin/

Mucous Membranes

NIC Intervention:

Training/Teaching

1. Urinary Bladder Training

2. Urinary Habit Training

3. Teaching Prescription

Medication

4. Teaching: Individual

5. Pelvic Muscle Exercise

6. Exercise/Therapy:

Ambulation

7. Communication

Enhancement

Management/Monitoring

1. Urinary Elimination

Management

2. Medication Management/

Administration

3. Medication Reconciliation

4. Fluid Management

Monitoring

5. Infection Protection

Care

1. Urinary Incontinence Care

2. Perineal Care

3. Tube Care: Urinary

Catheterization

4. Self-Care Assistance

5. Toileting Prompted

Voiding

Documentation

1. Surveillance: Safety

2. Documentation

NANDA-I Diagnoses:

1. The majority of the participants were female (78\%). Their average age was 81 years

2. The mean ACFI score (Toileting and Continence) was both 3.94 (standard deviation [SD] 0.24) and (mobility score: mean 3.75 ,

participants required a high level of care and assistance toileting.

3. After the intervention, there were significant improvements in the UC performance of all the patients; but one outcome measure cannot reduce
1. Uninary Elimination Impaired

2. Uninary Elimination Readiness for Enhanced

NOC Outcomes:

1. Urinary Elimination

2. Self-Care Toileting

3. Urinary Continence

NIC Intervention:

Training/Teaching

1. Urinary Bladder Training

2. Urinary Habit Training

3. Teaching: Individual

Ambulation

4. Communication

Enhancement

Management/Monitoring

1. Urinary Elimination

2. Management 
Table 2. NANDA/NOC/NIC for primary aim was incontinence management studies (continued)

\begin{tabular}{|c|c|c|c|c|}
\hline Author & Country & Method/Intervention & Participants & Results \\
\hline & & $\begin{array}{l}\text { UC care plan for each older } \\
\text { person } \\
\text { 3. The outcomes of the } \\
\text { intervention were evaluated } \\
2 \text { weeks later (T2). } \\
\text { 4. The post implementation } \\
\text { assessment was completed } \\
\text { in } 5 \text { weeks for monitoring } \\
\text { and assessing UC. } \\
\text { Study Outcomes: } \\
\text { 1. Pre-(T1) and post-(T2) } \\
\text { implementation was } \\
\text { conducted using data } \\
\text { collected by the telemonitoring } \\
\text { system for } 72 \text { hours at each } \\
\text { data point. } \\
\text { - Primary measure of weight } \\
\text { of urine voided into the } \\
\text { continence aid, number of } \\
\text { prescribed toileting events, w } \\
\text { actual toileting events; } \\
\text { successful toileting events, } \\
\text { voiding events into toilet: }\end{array}$ & $\begin{array}{l}\text { Education } \\
\text { (TAFE) college system. }\end{array}$ & $\begin{array}{l}\text { the number of toilet visits } \\
\text { prescribed in the UI care } \\
\text { plans, and the success rate } \\
\text { of toilet visits remained } \\
\text { unchanged. } \\
\text { 4. More people were assisted } \\
\text { to use toilet around } \\
\text { 4:30 p.m. and before } \\
\text { going to bed. } \\
\text { 5. Big improvement in UC } \\
\text { care was the significant } \\
\text { increase in the number of } \\
\text { times a person was offered } \\
\text { assistance to use a toilet, } \\
\text { increasing from an average } \\
\text { of two times to six times } \\
\text { in } 24 \text { hours. } \\
6 . \text { Assistance toileting was } \\
\text { provided to older people to } \\
\text { use the toilet over and above } \\
\text { what was prescribed in the } \\
\text { care plans p=0.033) after } \\
\text { the intervention. }\end{array}$ \\
\hline
\end{tabular}

\section{Vinsnes Nonwegian Method: Study area:}

A.G., et al.

(2012) Study Interventions: residents
Randomized controlled trial Four different $\mathrm{NHs}, \mathrm{N}=115$

1. Training program included Participants: physical activity and ADL $\quad n=98$ residents group, training. $n=98$ residents group, 2. Personal treatment goals $n=50$ ) were elicited for each subject: Intervention applied: - Training in transfer, walking All nurses in the ward ability, balance, muscle strength, and endurance were offered to individuals and groups.

- ADL training was performe when the resident needed help during meals, with personal care, or dressing. - Each subject was asked to participate in creative and/or entertaining activities.

3. All staff members on the wards were informed about each resident's treatment goals and offered personal supervision regarding how to provide "just the right challenge" to the residents. Study Outcomes:

1. The outcome measure of the 24 PWT was quantified prior to the intervention. 2. Then, it was quantified immediately after the intervention and 3 months after the intervention. physiotherapists and two occupational therapists provided the intervention

\section{NANDA/NOC/NIC}

Environmental

3. Management Safety

4. Medication Management / Administration

5. Fluid Management/

Monitoring

Care

1. Urinary retention care

2. Urinary incontinence care

3. Perineal Care

4. Bathing Self-Care Assistance

5. Self-Care Assistance Toileting

6. Prompted Voiding

Documentation

1. Documentation

\section{The average age at} enrollment was 85.7 years, and women were older than men (87.2 versus 81.1 years, $p=0.001$ )

2. The mean leakage of urine at baseline 3-month postintervention adjusted mean difference between the groups according to the amount of leakage was $191 \mathrm{~g}(\mathrm{p}=0.03)$.

3. The staff across the

NANDA-I Diagnoses:

1. Uninary Elimination Impaired Urinary

2. Elimination Readiness for Enhanced

NOC Outcomes:

1. Urinary Elimination

2. Self-Care Toileting

3. Urinary Continence

NIC Intervention:

Training/Teaching 24-hour time period had to understand why and how to complete the test and adhere to the process. 4. Altogether, 68 participants were included in the analysis (35 in the intervention group and 33 in the control group).

5. The average age was 84.3 years. The 3 -month postintervention adjusted mean difference between the groups according to amount of leakage was $191 \mathrm{~g}(\mathrm{p}=0.03)$.

- This result was statistically significant after adjusting for the baseline level, age, sex, and functional status. - The leakage increased in residents not receiving the experimental intervention while UI in the training
1. Urinary Bladder Training

2. Urinary Habit Training

3. Teaching: individual

4. Exercise Therapy:

Ambulation

5. Communication

Enhancement

Management/Monitoring

1. Urinary Elimination

Management

2. Environmental

Management

3. Fluid Management

/Monitoring

4. Weight Management

Care

1. Urinary incontinence care

2. Bathing Self-Bare Assistance

3.Self-Care Assistance Toileting 4. Prompted Voiding

Documentation

1. Documentation 
Table 2. NANDA/NOC/NIC for primary aim was incontinence management studies (continued)

\begin{tabular}{llll}
\hline Author Country Method/Intenvention & Participants & Results
\end{tabular}

group showed improvement.

9. Sackley UK
C.M., et al.
(2008)

10. Ouslander USA

J.G., et al.

(2005)

\section{Study area:}

Six care homes ( $N=211)$ were selected purposefully. Participants: $\mathrm{n}=33$ resident baseline $(\mathrm{n}=17$ in the intervention group and $n=16$ in the control group)

Intervention applied:

1. Staff training was available to all staff on a voluntary encouraged to walk or wheel to class basis, by continence nurse functional activities of daily completed questionnaires: living (standing up from a $\quad(n=38)$

chair, and strength, balance, endurance, and flexibility exercises).

- Music played during the class, and exercises were fun, making use of balloons and balls.

2. Staff education:

Study Outcomes:

- Formal urodynamic questionnaire investigation

- Mobility was measured using the Rivermead Mobility Index

-The short Orientation-

Memory-Concentration Test

- The Barthel Activity of Daily

Living Index

- Rivermead Mobility Index

- Feasibility was assessed by uptake and compliance.

\begin{abstract}
Method:
A randomized, controlled

study cross-over trial

Study Interventions:

1. Trained research staff

provided the FIT intervention

- Prompted voiding

combined with individualized

- Functionally oriented

endurance

- Strength-training exercises

2. This intervention was offered four times per day, five days per week, for 8 weeks. Group 1 received the intervention, while Group 2 served as a control group. Study Outcomes:

- Endurance was measured using observations of walking (or wheeling a
\end{abstract}

. The mobility training was delivered by three final -year student physiotherapists.

1. Twenty-nine residents $(88 \%)$ were female and aged 1 from 76 to 101 years (mean, 86 years). 2. Residents found the intervention acceptable and engaged well with the training.

3. In the intervention group incontinence decreased from 12/17 at baseline to $7 / 17$ at 6 weeks

4. In the intervention group and increased from 9/16

at baseline to 9/15 at 6 weeks

5. The Rivermead Mobility Index scores were better in the intervention group ( $n=17$; baseline, $6.1 ; 6$ weeks 6.2) compared with controls ( $n=16$; baseline, 5.9, 6 weeks, 4.75). 6. The intervention was feasible, well received, and had good compliance. 7. Forty-one staff members attended continence training - Thirty-eight completed questionnaires. The mean score was $5.5(\mathrm{SD}=2.5)$ out of a possible14

- They reported back positively, indicating felt need for additional continence training.

\section{Study area:}

Four nursing homes ( $N=528$ )

Participants:

1. An immediate intervention

(Group 1; $n=52$ )

2. A delayed intervention

group (Group 2; =55)

Intervention applied:

Six researchers:

1. On-site research staff were trained in the FIT intervention using a training video 2. To ensure the quality and consistency of the intervention, on-site supervisors conducted

periodic process observations and provided additional training and
1. The mean age was approximately $78,90 \%$ were men, and approximately $75 \%$ were Caucasian.

2. Three-quarters of the subjects had at least one psychiatric diagnosis. 3. There was a significant difference between two groups in the changes for all measures of endurance except total time walked or wheeled. 4. Urinary incontinence

d rates as measured by wet checks declined from a median of $54 \%$ to $25 \%$ in the immediate intervention group and increased in the control group from $41 \%$ to $50 \%$.
Impaired

2. Urinary Elimination

Readiness for Enhanced

3. Urinary Incontinence:

Functional

NOC Outcomes:

1. Urinary Elimination

2. Self-Care Toileting

3. Urinary Continence

NIC Intervention:

Training/teaching

1. Urinary Bladder Training

2. Urinary Habit Training

3. Teaching: Procedure/

treatment

4. Teaching: Individual

5. Pelvic Muscle Exercise

6. Exercise Therapy:

Ambulation

7. Communication

Enhancement

Management/Monitoring

1. Uninary Elimination

Management

2. Environmental

Management/

3. Fluid Management/

Monitoring

4. Weight Management

Care

1.Urinary retention care

2.Umary incontinence care

3.Self-Care Assistance: Toileting

4.Prompted Voiding

Documentation

1. Documentation

NANDA-I Diagnoses:

1. Uninary Elimination Impaired

2. Urinary Elimination

Readiness for Enhanced

3. Urinary retention

NOC Outcomes:

1. Uninary Elimination

2. Self-Care Toileting

3. Urinary Continence

NIC Intervention:

Training/Teaching

1. Urinary Bladder Training

2. Urinary Habit Training

3. Teaching: Procedure/

Treatment

4. Teaching: Individual

5. Exercise Therapy: Ambulation

6. Communication

Enhancement

Management/Monitoring

1. Urinary Elimination 
Table 2. NANDA/NOC/NIC for primary aim was incontinence management studies (continued)

\begin{tabular}{|c|c|c|c|c|c|}
\hline Author & Country & Method/Intervention & Participants & Results & NANDA/NOC/NIC \\
\hline & & $\begin{array}{l}\text { wheelchair), transfers, and } \\
\text { sit-to-stands } \\
\text { - Timed measures of } \\
\text { walking or wheeling a } \\
\text { wheelchair (mobility), sit- } \\
\text { to-stand exercises, } \\
\text { independence in locomotion } \\
\text { and toileting as assessed } \\
\text { using the Functional } \\
\text { Independence Measure (FIM), } \\
\text { - One-repetition maximum } \\
\text { weight for several measures } \\
\text { of upper and lower body } \\
\text { strength } \\
\text { - Continence was assessed } \\
\text { using physical checks if the }\end{array}$ & $\begin{array}{l}\text { enforcement on the } \\
\text { protocol as needed }\end{array}$ & $\begin{array}{l}\text { 5. Out of } 64 \text { participants } \\
\text { who completed the } \\
\text { intervention, } 43 \text { ( } 67 \%) \\
\text { were "responders" based } \\
\text { on maintenance or } \\
\text { improvement in at least } \\
\text { one measure of endurance, } \\
\text { strength, and urinary } \\
\text { incontinence. } \\
6 \text {. The older men in this } \\
\text { trial responded well to the } \\
\text { prompted voiding } \\
\text { component of FIT despite } \\
\text { a high risk of urinary } \\
\text { retention. }\end{array}$ & $\begin{array}{l}\text { Management } \\
\text { Care } \\
\text { 1. Urinary retention care } \\
\text { 2. Urinary incontinence care } \\
\text { 3. Self-Care Assistance Toileting } \\
\text { 4. Prompted Voiding } \\
\text { Documentation } \\
\text { 1. Surveillance: Safety } \\
\text { 2. Documentation }\end{array}$ \\
\hline
\end{tabular}

made, and information about the development of pressure ulcers, treatment, healing time, daily activities, risks of pressure ulcers, and incontinence were documented. We thus matched three possible NOC outcomes to these activities: "Urinary Elimination," "Tissue Integrity: Skin and Mucous Membranes," and "Urinary Continence."

\section{Incontinence Management Studies}

In this group of studies, researchers aimed to decrease episodes of incontinence and improve continence. They were conducted in 59 $\mathrm{NH}$ settings with $\mathrm{n}=669$ residents. The mean ages of the residents ranged from approximately 78.0 to 86.0 years old (Table 2).

In the study Booth et al. (2013), 70 people had an overactive bladder. In the study by Aslan et al. (2008), the UI types were determined to be Stress, Urge, and Mixed Incontinence. The studies matched possible NANDA diagnoses of "Urinary Elimination Impaired," "Urinary Elimination Readiness for Enhanced," "Urinary incontinence: Urge," and "Urinary Retention."

In one study, $\mathrm{NH}$ staff gave a 12-session Transcutaneous Posterior Tibial Nerve Stimulation (TPTNS) treatment program and evaluated postvoid residual urine volume (Booth et al., 2013). In another study, bladder training and
Kegel exercises were given to the retreatment group (Aslan et al., 2008). These possible NIC interventions selected for this study came under the "Training/Teaching" heading ("Urinary Bladder Training," "Urinary Habit Training," "Teaching: Procedure/Treatment," "Teaching: Individual," "Pelvic Muscle Exercise"), the "Management/Monitoring" heading ("Urinary Elimination Management," "Infection Protection," "Pain Management"), and the "Care" heading ("Urinary Retention Care," "Urinary Incontinence Care," "Perineal Care," "Self-Care Assistance Toileting," "Prompted Voiding").

The acceptability of the TPTNS was high throughout, with no reports of any adverse effects, either by the participant or staff. Urinary symptoms improved in 13 members $(87 \%)$ of the TPTNS group. The intervention can be administered by a nurse, physician, or physiotherapist with only minimal training required (Booth et al., 2013). In another study, the pelvic floor muscle strength was $52 \%$ in the treatment group and 48\% in the control group (Aslan et al., 2008). For these studies, we selected "Urinary Elimination" and "Self-Care Toileting Urinary Continence" as the possible NOC outcomes.

Three studies aimed to investigate whether it was effective to increase the intake of fluids 
to encourage urination in a toilet (Lin, 2013; Schnelle et al., 2010; Tanaka et al., 2009). Possible NANDA-I diagnoses were "Urinary Elimination Impaired," "Urinary Elimination Readiness for Enhanced," "Urinary Incontinence: Urge," "Urinary Incontinence: Overflow," and "Urinary Incontinence: Functional."

In one study, the nursing interventions included increasing fluid intake, encouraging urination in a toilet, encouraging spending over 6 hours out of bed, reducing the time spent in wet diapers, and choosing diapers with smaller pads (Tanaka et al., 2009). In another study (Lin, 2013), the participants were assigned to a common fluid regimen chosen by their nursing administrator for a period of six weeks. The accuracy of the nurses' recording of the intake and output checklist was recorded (Lin 2013), and the same strategy was applied in a multicomponent intervention study (Schnelle et al., 2010). The possible NIC interventions under the "Training/Teaching" heading were determined to be "Urinary Bladder Training," "Urinary Habit Training," "Communication Enhancement;" under the "Management/Monitoring" heading "Urinary Elimination Management," "Fluid Management/Monitoring," "Infection Protection," "Specimen Management;" under the "Care" heading "Urinary Incontinence Care," "Perineal Care," "Tube Care: Urinary Catheterization," "UC. Intermittent," "Self-Care Assistance Toileting," "Prompted Voiding;" and under the "Documentation" heading, "Documentation."

In the baseline data, one study determined which $\mathrm{NH}$ staff members were not aware of the importance of monitoring fluid volume, even though they encouraged residents to drink often (Tanaka et al., 2009). In another study, the prevalence of symptomatic bacteria at baseline was 29.7\%; after the intervention, it was $17.6 \%$ (Lin, 2013). In the multicomponent intervention study, the fluid intake, the number of calories from snacks between meals, the number of activities, and the number of minutes spent in activities of the intervention group increased significantly compared to the baseline and control group $(p<0.05)$ (Schnelle et al., 2010). The possible NOC outcomes selected for these studies were "Urinary Elimination," "Self-Care Toileting," "Urinary Continence," "Tissue Integrity: Skin and Mucous Membranes," and "Medication Response, Tissue Integrity."

Two studies investigated individual care plans designed to help keep the elderly population drier and less prone to falls, urinary tract infections, and pressure sores (Klay $\&$ Marfyak, 2005; Yu et al., 2014). Possible NANDA-I diagnoses selected for these studies were "Urinary Elimination Impaired," "Urinary Elimination Readiness for Enhanced," "Urinary Incontinence: Overflow," "Urinary Incontinence: Urge."

In one of these studies, a continence nurse specialist $(\mathrm{RN})$ recorded incontinent episodes for each participant for 1 week and then designed an individualized care plan (Klay \& Marfyak, 2005). The other study aimed to explore the effects of a telemonitoring care planning system (Yu et al., 2014). Data included the time of any toilet event, whether it was successful or not, the time when a continence aid was changed, the weight of the pad, and the time and amount of fluid intake. Possible NIC interventions under the "Training/Teaching" heading were "Urinary Bladder Training," "Urinary Habit," "Training," "Teaching: Prescription Medication," "Teaching: Individual," "Pelvic Muscle Exercise," "Exercise/Therapy: Ambulation," and "Communication Enhancement;" under the "Management/Monitoring" heading were "Urinary Elimination Management," "Medication Management/Administration," "Medication Reconciliation," "Fluid Management/Monitoring," and "Infection Protection;" under the "Care" heading were "Urinary Incon- 
tinence Carem," "Perineal Care," "Tube Care Urinary Catheterization," "Self-Care Assistance Toileting," and "Prompted Voiding;" and under the "Documentation" heading "Surveillance: Safety, Documentation."

In the first study, participants were treated with biofeedback. They were also better able to notice the signal to void. Urinary tract infection rates dropped from $5 \%$ to $1 \%$, pressure sore rates dropped from $80 \%$ to $45 \%$, and falls decreased by more than 50\% (Klay \& Marfyak, 2005). In the other study, there were significant improvements in the UC performance of all participants, and nurses became more person centered and responsive to toileting requests (Yu et al., 2014). The possible NOC outcomes selected were "Urinary Elimination," "Self-Care Toileting," "Urinary Continence," "Medication Response," and "Tissue Integrity: Skin and Mucous Membranes."

In three studies, the aim was to investigate individualized training programs designed to improve the activity of daily living (ADL) and physical capacity among residents in $\mathrm{NHs}$ (Ouslander et al., 2005; Sackley et al., 2008; Vinsnes et al., 2012). The functional status related to toilet habits was registered. Possible NANDA diagnoses were "Urinary Elimination Impaired," "Urinary Elimination Readiness for Enhanced," "Urinary Incontinence: Functional," and "Urinary Retention."

The training programs, included physical activity and ADL training (Vinsnes et al., 2012), activities in which the participants were encouraged to walk or wheel, or exercises to provide strength, balance, endurance, and flexibility (Sackley et al., 2008), or Functional Incidental Training (FIT) that included prompted voiding and functionally oriented endurance and strengthening exercises (Ouslander et al., 2005). Each subject was asked to participate in creative and/or entertaining activities (Vinsnes et al., 2012), and music was played during fun exercises, also making use of balloons and balls (Sackley et al., 2008). During the studies, all staff members on the wards were informed about each resident's treatment goals and offered personal supervision. Residents' progress was reviewed, and their views were gathered and documented (Ouslander et al., 2005; Sackley et al., 2008; Vinsnes et al., 2012). The possible NIC interventions in the three studies under the "Training/Teaching" heading were "Urinary Bladder Training," "Urinary Habit Training," "Teaching: Procedure/Treatment," "Teaching: Individual," "Pelvic Muscle Exercise," "Exercise Therapy: Ambulation," and "Communication Enhancement;" under the "Management/ Monitoring" heading were "Urinary Elimination Management," "Environmental Management," "Fluid Management/Monitoring," and "Weight Management;" under the "Care" heading were "Urinary Retention Care," "Urinary Incontinence Care," "Self-Care Assistance: Toileting," and "Prompted Voiding;" and under the "Documentation" heading, "Documentation."

In all three studies, the interventions were feasible and well received. In one study, the researcher expected that the staff understand why and how to complete the intervention and that they would adhere to the process (Sackley et al., 2008). In another study, nurses gave verbal feedback, which indicated that residents valued the classes (Ouslander et al., 2005). The NOC outcomes selected included "Urinary Elimination," "Self-Care Toileting," and "Urinary Continence."

\section{DISCUSSION}

We reviewed these studies because incontinence is an important health and nursing issue in $\mathrm{NHs}$, and there is a lack of intervention studies performed by nurses on factors associated with UI. The literature includes a number of different types of UI nursing studies, but even these studies do not provide for nursing diag- 
noses, assessment, intervention, and evaluation for UI outcomes. They are not adequate to help nurses make logical and systematic decisions about diagnoses and do not allow for the development of databases to document nursing care (Ehlman et al., 2012; Felix, Thostenson, Bursac, \& Bradway, 2013; Resnick et al., 2006; Roe et al., 2015). We reviewed studies from eight different countries, with five studies conducted the United States. As a result, the findings may not be transferable to other countries or cultures, but they do provide a common view for nurses about nursing activities related to UI (Table 1).

The majority of residents in the studies were aged $>70$ years, and they needed nursing aids to manage UI (Al-Samarrai et al., 2007; Beeckman, Verhaeghe \& Defloor, 2011; Palese et al., 2011; Thompson, Langemo, Anderson, Hanson, \& Hunter, 2005). Generally, it is known that elderly people receive $\mathrm{NH}$ care to meet their care needs, including those related to UI. Therefore, it is not surprising that the nursing interventions performed in the studies included activities such as assisted toileting, incontinence care, and being encouraged to walk or wheel (Felix et al., 2013; Resnick et al., 2006).

Different limitations were observed in different studies, such as having a smaller sample size or being based on a single center (Al-Samarrai et al., 2007; Booth et al., 2013; Lin, 2013; Klay $\&$ Marfyak, 2005; Yu et al., 2014), purposive sampling (Palese et al., 2011; Sackley et al., 2008), inadequate follow-up (Lin, 2013; Schnelle et al., 2010; Thompson et al., 2005); documentation problems (Tanaka et al., 2009; Thompson et al., 2005), and outcomes measurement (Beeckman, Verhaeghe, Defloor, Schoonhoven, \& Vanderwee, 2011; Lin, 2013; Ouslander et al., 2005). Although some of the studies focused on a very specific area of UI nursing care (Aslan et al., 2008; Klay \& Marfyak, 2005; Palese et al., 2011; Thompson et al., 2005), they cannot be standardized for UI care for the elderly.
Nursing diagnoses describe actual or potential problems resolved through intervention, and focus on wellness (Johnson et al., 2012; Moorhead, Johnson, Maas, \& Swanson, 2014). In this systematic review, the most common NANDA diagnosis was "Urinary Elimination Readiness for Enhanced," and the least common was "Urinary Incontinence: Overflow" (Tables 1, Table 2). Nursing studies can help nurses who provide care to elderly people with incontinence in $\mathrm{NHs}$ to gather data to screen for etiologies and symptoms, and to focus and structure information about UI (Voith, 2000; Noh \& Lee, 2015). Almost all the studies in this review were intended to improve continence and alleviate negative symptoms, but in some of them, the type of incontinence was overlooked in planning the nursing interventions (Al-Samarrai et al., 2007; Ouslander et al., 2005; Palese et al., 2011).

This study found 167 possible NIC interventions in the sources. In these 14 studies, nurses applied various nursing practices (Tables 1, Table 2). Determining which nursing interventions to use is influenced by a variety of factors. These factors affecting the nursing intervention selected include the desired patient outcomes, characteristics of the diagnosis, the research base associated with the intervention, the feasibility of implementing the intervention, the acceptability of the intervention to the patient, and the capability of the nurse (Bulechek, Butvher, Dochtermanj, \& Wagner, 2013; Johnson et al., 2012).

Data obtained from nursing assessments and nurse's knowledge level about UI allows nurses make the correct nursing diagnosis in accordance with the type of UI experienced (Aslan et al., 2008; Ouslander et al., 2005; Vinsnes et al., 2012). It has been suggested that UI training programs should be mandatory for all nursing home staff (Ouslander et al., 2005). In the studies, nurse continence specialists gave UI training programs using different education techniques (Al-Samar- 
rai et al., 2007; Beeckman et al., 2011; Palese et al., 2011; Thompson et al., 2005). The studies showed that educating health care professionals regarding UI may have a positive effect on staff and resident outcomes (Palmer, 2008; Park et al., 2015; Resnick et al., 2006; Roe et al., 2015).

In the current review, the most matched possible NOC outcomes were "Urinary Elimination Outcomes," and the least matched NOC outcomes were "Self Care: Toileting Outcomes" (Tables 1, Table 2). Although much nursing time, energy, and cost are invested in resolving urinary problems (Ersser, Getliffe, Voegeli, \& Regan, 2005; Park et al., 2015), diagnosis and treatment are often shared between the nurse and another health professional, and these nursing efforts generally remain undocumented (Bardsley, 2014; De Moraes et al., 2009; Tanaka et al., 2009). The NOC outcomes allow for the quantification of the patient's state, behavior, and perception, and they outline what is expected to occur at different points in time during incontinence care (Johnson et al., 2012; Moorhead et al., 2014; Noh \& Lee, 2015).

The four studies that were primarily aimed at skin integrity and skin care looked at implementing different skin care protocols and products (Al-Samarrai et al., 2007; Beeckman et al., 2011; Palese et al., 2011; Thompson et al., 2005). Inappropriate management can lead to breaks in the skin, incontinence dermatitis, and pressure ulcers, which can be very serious complications for the resident (Ersser et al., 2005; Rodriguez et al., 2007). A few studies focused on the cost-effectiveness (time, staff, equipment) and although the programs used were effective in reducing the care costs for episodes of incontinence, this was difficult to maintain throughout the follow-up period (Felix et al., 2013; Flanagan et al., 2015). In the study by Thomson et al. (2005), the PrUs prevalence $(4.8 \%)$ and incidence $(8.9 \%)$ decreased. The healing time significantly decreased from
23 days to 16 days. Chronic wounds in older adults took approximately 26-42 days to heal (Esser et al., 2005). It was thought that educating and monitoring nurses and encouraging them to study guidelines had an important effect on the result (Bliss et al., 2006; Ersser et al., 2005; Flanagan et al., 2011; Park et al., 2015).

In this review, two of the studies included intervention on bladder function using TPNE (Booth et al., 2013) and Kegel exercises (Aslan et al., 2008). These studies demonstrated a significant decrease in UI frequencies, and both interventions could be successfully administered by nurses. Nursing interventions were supported by research evidence to improve patient outcomes and the quality of clinical practice. Nurses seek continually the answer if the intervention being given is the best possible practice (Bulechek et al., 2013; Resnick et al., 2006).

Multicomponent intervention studies aimed to determine the effect of interventions that combined toileting assistance, exercise, and improved food and fluid intake on UI (Lin, 2013; Schnelle et al., 2010; Tanaka et al., 2009; Yu et al., 2014). In the literature, most of the studies offered at least $2000 \mathrm{ml}$ fluid to prevent the risk of the dehydration and symptoms of bacteria (Bardsley et al., 2014; Heardman \& Kamitsuru, 2014; Schnelle et al., 2010; Lin, 2013). These studies found that resident did not take in enough fluid, thus nursing staff were not aware of this situation. Using the NIC/NOC intervention for fluid intake activity may help nurses to manage and monitor to fluid intake in patients (Bulechek et al., 2013; Johnson et al., 2012; Moorhead et al., 2014).

Several studies suggested that individualized incontinence nursing care plans were able to reduce the rate of $\mathrm{UI}$ among $\mathrm{NH}$ residents (Klay $\&$ Marfyak, 2005; Palmer, 2008; Yu et al., 2014). After the nurses' interventions, there were significant improvements in $\mathrm{UC}$, but the number of toilet visits cannot be prescribed in the UI care plans, and the success rate of toilet visits remained un- 
changed (Klay \& Marfyak, 2005; Yu et al., 2014). A big improvement in UC care came about through a significant increase in the awareness among care staff about UI. This awareness led care staff to be more person centered and responsive to toilet requests (Flanagan et al., 2015; Moorhead et al., 2014; Schnelle et al., 2003).

Studies included physical activity, ADL training, and FIT programs, and nurses observed residents' progress, gave verbal feedback, and documented each resident individually (Ouslander et al., 2005; Sackley et al., 2008; Vinsnes et al., 2012). These studies show that if nursing practices and the nursing care provided to patients are documented, it possible to capture all of the contextual elements of the nursing care process (Ouslander et al., 2005; Sackley et al., 2008; Vinsnes et al., 2012). Responses to questionnaire forms indicated that nurses needed to develop their basic knowledge in this area, and they reported back positively, indicating that they felt the need for additional continence training (Ouslander et al., 2005).

\section{CONCLUSION}

Many questions of interest related to elderly with UI cannot yet be answered, and it is not yet possible to systematically evaluate the effectiveness of nursing care. Most of the research data related to UI are not included in national/international databases of nursing practice. There is a pressing need to identify and systematically collect more data in formats that can be compared and incorporated in databases. Using NOC/NIC Linkages to NANDA-I may provide new nursing perspectives on nonstandardized research. Future studies may allow for the comparison of data across different locations worldwide, enabling nurses to use the results of these studies in evidence-based practices.

Informed Consent: This review was written with searching on databases and the articles found by articles was reviewed. So we did not work with patients or parents. There is no need informed consent.

Peer-review: Externally peer-reviewed.

Author Contributions: Concept - H.B.; Design - H.B., S.M. Supervision - S.M.; Resources - D.G., S.O.; Materials - H.B., M.S.; Data Collection and/or Processing - H.B., M.S.; Analysis and/or Interpretation - H.B., M.S.; Literature Search - H.B., D.G., M.S., S.O; Writing Manuscript - H.B., S.M., D.G., M.S., S.O. Critical Review H.B., S.M., D.G., M.S., S.O.; Other - H.B., D.G. Y.B.Ü.

Conflict of Interest: The authors have no conflicts of interest to declare.

Financial Disclosure: The authors declared that this study has received no financial support.

\section{References}

Al-Samarrai, N. R., Uman, G. C., Al-Samarrai, T. \& Alessi, C. A. (2007). Introducing a new incontinence management system for nursing home residents. Journal of the American Medical Directors Association, 8(4), 253-261. [CrossRef]

Aslan, E., Komurcu, N., Beji, N., \& Yalcin, O. (2008). Bladder training and kegel exercises for women with urinary complaints living in a rest home. Gerontology, 54(4), 224-231. [CrossRef]

Bardsley, A. (2014). Promoting urinary continence in older women. Nursing Standard, 29(8), 42-51. [CrossRef]

Beeckman, D., Verhaeghe, S., Defloor, T., Schoonhoven, L., \& Vanderwee, K. (2011). A 3-in-1 perineal care washcloth impregnated with dimethicone $3 \%$ versus water and ph neutral soap to prevent and treat incontinence- associated dermatitis. Journal of Wound, Ostomy \& Continence Nursing, 38(6), 627-634. [CrossRef]

Blissi D. Z., Kay-Saviki K., Harmsi S., Fani Q., \& Wyman, J.F. (2006). Prevalence and correlates of perineal dermatitis in nursing home res idents. Nursing Research, 55(4), 243-251. [CrossRef]
Booth, J., Hagen, S., McClurg, D., Norton, C., MacInnes, C., Collins B., et al. (2013). A feasibility study of transcutaneous posterior tibial nerve stimulation for bladder and bowel dysfunction in elderly adults in residential care. Journal of the American Medical Directors Association, 14(4), 270-274. [CrossRef]

Bulechek, G., Butcher, H., Dochterman, J., \& Wagner, C. (Eds.). (2013). Nursing interventions classification (NIC) (6th ed.). USA, St. Louis: Elsevier.

De Moraes-Lopes, M. H. B., Siqueire-Ortega, N.R., Massad, E., \& Marin, D. F. (2009). Model for differential nursing diagnosis of alterations in urinary elimination based on fuzzy logic. Computers, Informatics, Nursing, 27(5), 324-329. [CrossRef]

Ehlman, K., Wilsn, A., Dugger, R., Eggleston, B., Coudret, N., \& Mathis, S. (2012). Nursing home staff members' attitudes and knowledge about urinary incontinence: the impact of technology and training. Urologic Nursing, 32(4), 205-213. [CrossRef]

Ersser, S.J., Getliffe, K., Voegeli, D., \& Regan, S. (2005). A critical review of the inter-relationship between skin vulnerability 
and urinary incontinence and related nursing intervention. International Journal of Nursing Studies, 42(7), 823-835. [CrossRef]

Felix, H. C., Thostenson, J. D., Bursac, Z., \& Bradway, C. (2013). Effect of weight on indwelling catheter use among long-term care facility residents. Urologic Nursing, 33(4), 194-200. [CrossRef]

Flanagan, L., Roe, B., Jack, B, Barrett, J., Chung, C., \& Williams, K. S. (2011). Systematic review of care intervention studies for the management of incontinence and promotion of continence in older people in care homes with urinary incontinence as the primary focus (1966-2010). Geriatrics Gerontology International, 12(4), 600-611. [CrossRef]

Flanagan, L., Roe, B. Jack, B, Shaw, C., Williams, K. S., Chung, A., \& Barrett, J. (2015). Factors with the management of incontinence and promotion of continence in older people in care homes. Journal of Advanced Nursing, 70(3), 476-496. [CrossRef]

Herdman, T.H. \& Kamitsuru, S. (Eds.), (2014). NANDA International nursing diagnoses: definitions \& classification, 2015-2017. USA, Oxford: Wiley Blackwell.. [CrossRef]

Johnson, M., Bulechek, G. M., Dochterman, J. M. M., Maas, M. L., Moorhead, S., Swanson, E. \& Butcher, H.K. (Eds.), (2012). NOC and NIC linkages to NANDA-I and clinical conditions: Supporting critical reasoning and quality care. USA, St. Louis: Elsevier Mosby.

Klay, M., \& Marfyak, K. (2005). Use of a continence nurse specialist in an extended care facility. Urologic Nursing, 25(2), 101-108.

Lin, S. Y. (2013). A Pilot Study: Fluid intake and bacteriuria in nursing home residents in Southern Taiwan. Nursing Research, 62(1), 67-72. [CrossRef]

Moher, D., Liberati, A., Tetzlaff, J., Altman, D. G., \& the PRISMA Group. (2009). Reprint-preferred reporting items for systematic reviews and meta analyses: The PRISMA Statement. Physical Therapy, 89(9), 873-880.

Moorhead, S., Johnson, M., Maas, M.L. \& Swanson, E. (Eds), (2014). Nursing outcomes classification (NOC): measurement of health outcomes (5 ${ }^{\text {th }}$ Edition), USA, St. Louis: Edition 5, Elsevier.

Noh, H. K., \& Lee, E. (2015). Relationships among NANDA-I diagnoses, nursing outcomes classification, and nursing interventions classification by nursing students for patients in medical-surgical units in Korea. International Journal of Nursing Knowledge Volume, 26(1), 43-51. [CrossRef]
Ouslander, J. G., Griffiths, P. C., McConnell, E., Riolo, L., Kutner, M., \& Schnelle, J. (2005). Functional İncidental training: a randomized, controlled, crossover trial in veterans affairs nursing homes. Journal of the American Geriatrics Society, 53(7), 1091-1100. [CrossRef]

Palese, A., \& Carniel, G. (2011). The effects of a multi-intervention incontinence care program on clinical, economic, and environmental outcomes. Journal of Wound, Ostomy \& Continence Nursing, 38(2), 177-183. [CrossRef]

Palmer, M. H. (2008). Urinary incontinence quality improvement in nursing homes: where have we been? where are we going? society of urologic nurses and associates. Urologic Nursing, 28(6), 439-444.

Park, S., De Gagne, J. C., So, A., \& Palmer, M. H. (2015). Attitudes, beliefs, and practices in registered nurses and care aids about urinary incontinence in Korean nursing homes: A cross-sectional survey. Journal of Wound, Ostomy \& Continence Nursing, 42(2), 183-189. [CrossRef]

Resnick, B., Keilman, L. J., Calabrese, B. Parmelee, P., Lawhorne, L., Pilet, J., \& Ouslander, J. (2006). Nursing staff beliefs and expectations about continence care in nursing homes. Wound Ostomy Continence Nursing, 33(6), 610-618. [CrossRef]

Rodriguez, N. A., Sackley, C.M., \& Badger, FJ. (2007). Exploring the facets of continence care: A continence survey of care homes for older people in Birmingham. Journal of Clinical Nursing, 16(5), 954-962. [CrossRef]

Roe, B., Lisa Flanagan, L., \& Maden, M. (2015). Systematic review of systematic reviews for the management of urinary incontinence and promotion of continence using conservative behavioral approaches in older people in care homes. Journal of Advanced Nursing, 71(7), 1464-1483. [CrossRef]

Sackley, C. M, Rodriguez, N. A, Berg, M., Badger, F., Besemer, J., Reeuwijk, K., \& Wely, L. (2008). A phase II exploratory cluster randomized controlled trial of a group mobility training and staff education intervention to promote urinary continence in UK care homes. Clinical Rehabilitation, 22(8), 714-721. [CrossRef]

Schnelle, J. F, Kapur, K., Alessi, C., Osterweil, D., Beck, J. G., Al-Samarrai, N. R., \& Ouslander, J. G. (2003). Does an exercise and incontinence intervention save healthcare costs in a nursing home population? Journal of the American Geriatrics Society, 51(2), 161-168. [CrossRef] 